\title{
ATTITUDE TOWARDS THE LGBTQ COIMMUNITY THROUGH THE AGES: INDIAN SOCIETY AND LITERATURE
}

KEY WORDS: LGBT,

Homophobia, Literature, History, Fundamental Rights

\section{Gaganjot Kaur*}

\section{Aradhita Dasgupta}

The Bhawanipur Education Society College, University of Calcutta, Kolkata. *Corresponding Author

\section{The Bhawanipur Education Society College, University of Calcutta, Kolkata.}

E It has been widely observed that LGBT Literature in India is scarce compared to its foreign counterpart. One of the major reasons for this is the archaic and deep rooted institutional 'othering' that is meted out to the individuals belonging to this community. This research paper deals with the literature of the few authors who have so eloquently written about LGBTQ stories and the ordeals they have to face to publish their works in a (still very) homophobic and transphobic India. This paper has been written with the sole intention of providing a one-stop information hub about the evolution of LGBTQ Literature in India.

\section{UNDERSTANDING LGBTQ}

\section{- GENDER IDENTITY AND GENDER EXPRESSION}

Traditionally one's assigned biological sex at birth depends on their sex chromosomes. For instance, a person who has $\mathrm{Y}$ chromosome at birth is called a 'male' but they may lack some genes that make up for some specific male characteristics due to a varied production of hormones. People who do not specifically fit into the binary of male or female are termed as intersex.

Gender Identity and Gender Expression is different from the biologically constructed sex. Gender Identity is one's own sense of their gender while Gender Expression is how they present themselves to the world.

However, there are various other modes of identification apart from the 'man- woman dichotomy'. Some individuals identify as Multiple Gender, some as Transgender, other have a Gender fluid identity and others may term themselves as agender.

One thing to understand is that a person's biological sex or gender identity do not determine their sexual orientation. The broad spectrum of sexual orientation includes Heterosexuality (attracted to the opposite gender), Homosexuality (attracted to the same gender), Bisexual (attracted to two genders), Pansexual (attracted to an individual regardless of their gender identity) and Asexual (may not experience sexual attraction).

People from the broad gender identity spectrum can choose any pronoun/s to refer themselves to- such as He/ Him/ His, She/ Her/ Hers, They/ Them /Theirs. When people who are addressed and identified as anything other than their preferred gender identity it is known as being 'misgendered'. For instance, addressing a trans woman as 'he'.

\section{- WHAT IS LGBTQ+?}

LGBTQ is an acronym that stands for Lesbian, Gay, Bisexual, Trans and Queer. L stands for Lesbian/s, a term assigned to women who are sexually attracted to women. G stands for Gay/s, which refers to men who are sexually attracted to men. B stands for Bisexual/s, which refers to an individual who are attracted to both men and women. T stands for Transgender/s, referring to individuals who are born with a biological sex but may not adhere to it and assign themselves a new gender identity. Q stands for Queer, an umbrella term for individuals who fit in and identify to any of the above-mentioned terminologies.

\section{LGBT NARRATIVES IN EUROPEAN LITERATURE}

\section{Ancient Greece and Rome:}

Works as early as Plato's Symposium and Homer's Iliad describe same-sex partnerships, including one between two heroes of the Iliad, Achilles and Patroclus. Iconic Greek poet Sappho is known not only for her ahead-of-her-time lyrical poems but also for their themes of female sexuality and love and as a result of the rigid times her works were burned for their portrayals of lesbianism.

\section{The Renaissance:}

Many have offered LGBTQ interpretations of Shakespeare's, Twelfth Night, The Merchant of Venice and his erotic sonnets. In spite of that the addressing homosexuality in the Renaissance times is not direct. Though there are exceptions in the works like Shakespeare's Sonnets, Marlowe's Edward the Second, Richard Barnfield's The Affectionate Shepherd.

\section{Eighteenth Century:}

The homoerotic relationships were portrayed in works like The Diaries of Anne Lister and the poetry of Katherine Philips were actually a private affair in the society.

Matthew Lewis, William Thomas Beckford and Francis Lathom were gay and expressed homosexual themes in an acceptable format with the help of genres like Gothic and horror fiction.

Nineteenth Century: The nineteenth century LGBTQ literature was indirect and subversive. A Year in Arcadia: Kyllenion (1805) by Augustus, Duke of Saxe-Gotha-Altenburg is one of the earliest novels to show same sex male relationship. Writers like Arthur Rimbaud who himself was a proud gay man wrote poems that hinted at his sexual identity. No publisher of the late 1800s would touch Walt Whitman's masterwork, Leaves of Grass, which spoke with a bold voice about subjects that vocal critics considered obscene, especially in its homoerotic passages. Oscar Wilde, Marcel Proust, Emily Dickinson have indicated sublime references to LGBTQ identity and relationships into many works.

\section{THETRIAL OF OSCARWILDE}

OscarWilde underwent a trial for indecency in 1895 when his affair with a British aristocrat were made public.

Twentieth Century: James Baldwin, Truman Capote, E.M. Forster's Maurice (, 1971), Allen Ginsberg, Audre Lorde, Diane di Prima, Adrienne Rich, Thomas Mann's Death in Venice (1912), and Virginia Woolf transgressed social boundaries and brought LGBTQ plots to the limelight.

André Gide's The Immoralist (1902) sketches a newly married man discovering his sexuality through his attraction to a number of young Arab boys. Giovanni's Room (1956) by James 
Baldwin is another milestone. Allen Drury's Advise and Consent (1959) shows the blackmailing of a young US senator who is hiding a secret wartime homosexual tryst.

Radclyffe Hall's The Well of Loneliness in 1928 , changed the way gender and sexual identities were articulated. The landmark case of freedom of speech marks an important event in British literary history.

Prominent contemporary authors like Virginia Woolf, G. B. Shaw,T.S.

Eliot, Arnold Bennett and more spoke in favour of Ms. Hall and her book.

21st Century : The winner of 2018's Pulitzer Prize in Fiction, Andrew Sean Greer's Less, a story about a gay writer Arthur Less while he travels the world on a literary tour to grieve the loss of his male lover. Simon vs. the Homo Sapiens Agenda by Becky Abertalli published in 2015 is coming of age novel about coming out of a teenager. The Song of Achilles by Madeline Miller (2011) and The Gentlemen's Guide to Vice and Virtue by Mackenzi Lee (2017).

\section{HOMOSEXUALITY IN INDIA AND HER LITERATURE}

Societal attitudes towards same-sex relationships have varied over time and place.

According to the survey conducted in the sample of 50 people ranging from the age group of $18-60+$ years, $71.4 \%$ had accepted that religion plays a major role in shaping opinions and mentality towards LGBTQ people mostly bordering on homophobia and transphobia.

On the contrary when one looks at the history of the Indian subcontinent, they find religion and culture accepting, normalising and even celebrating the broad spectrum of gender identities and expressions and sexual orientations.

\section{4 of 20}

\section{- ANCIENT HINDU SOCIETY}

The Laws of Manu, the foundational work of Hindu law, mentions a "third sex", members of which may engage in nontraditional gender expression and homosexual activities. The Kama Sutra, written in the 4 th century by V tsy yana is a testament to the liberal and less rigid attitudes of the time. According to the Kama Sutra: "There are also third-sex citizens, sometimes greatly attached to one another and with complete faith in one another, who get married together."

Rigveda, one of the four canonical sacred texts of Hinduism says "Vikriti Evam Prakriti" (meaning what seems unnatural is also natural).

The Arthashastra, an ancient Indian treatise on statecraft, mentions a wide variety of sexual practices which, whether performed with a man or a woman, were sought to be punished with the lowest grade of fine. While homosexual intercourse was not sanctioned, it was treated as a 'very minor offence', and several kinds of heterosexual intercourse were punished more severely.

Of the many deities considered the patrons of the transgender community, one such is Devi Bahuchara.

One of the myths concerns a king who prayed before Devi Bahuchara for a son. With the blessings of the goddess, son Jetho is born who is impotent. One night the Devi appears in his dreams and orders him to cut off his genitals and become one of her servants.

Devi Bahuchara singled out impotent men to order them to submit to a fate similar to Jetho's and if they disobeyed she punished them by cursing impotency on them for the next seven incarnations.
In the second myth, Devi Bahuchara and her sisters were attacked by bandits and in order to avoid being raped she cut off her breasts and her sisters died by suicide. She cursed the men with impotence and stated the only way to seek redemption was to give up their masculinity. Furthermore, they were to dress up as a woman and worship her as a goddess. The curse of impotency is akin to castration.

A question can strike one's mind - Why is being emasculated considered a punishment or a curse?

This maybe a reason why people in the survey considered religion to be a reason for perpetrating homophobia and transphobia.

\section{5 of 20}

In certain versions of Ram's mythical story, when he was banished for fourteen years along with Sita and Lakshman, the faithful citizens had followed him to the outskirts of Ayodhya where he commanded all men and women to go back to Ayodhya and wait for his return. Only the 'hijras' had stayed there waiting for him for fourteen years as he had forgotten to give them specific directions regarding their duties.

The Hindu god Shiva is depicted as Ardhanarishwara, an androgynous God. It is portrayed as a figure split into two vertical halves merged within the same body. The hermaphrodites, homosexuals and transvestites are associated with the imagery of Ardhanarishwara.

The Bhakti poets like Kabir and Jiyasi often presented themselves as females in their verses, in love with a male God.

Devdutt Pattanaik observes that "Amongst scenes from epics and legends [etched on walls of old temples], one invariably finds erotic images... [and] hidden in niches as in Khajuraho, one does find images of either women erotically embracing other women or men displaying their genitals to each other."

\section{LGBTQ IN BENGAL KRITTIVASA RAMAYANA}

The most popular version of Ramayana is by the 14th C. poet Krittivasa. In the myth Sagara of Ayodhya's dynasty was threatened when most of his sons were killed due to Sage Kapila's wrath. The last heir Dilipa died childless.

Before dying he went in search of the Ganga and prayed and meditated penance, living on water and fasting but was not successful. King Dilipa died leaving the city of Ayodhya kingless. Brahma and Indra were worried that the kingdom remained empty. On their request Shiva went to Dilipa's two queens and blessed them with a son who was to born as a result of intercourse between the two women.

The child born was a lump of flesh. Both the women distraught left the child on the banks of river Sarayu. On the suggestion of sage Vashistha left their son on the road, where the sage Ashtavakra saw the child from a distance. The powerful Ashtavakra blessed the child to be rid of his physical deformity and become like Madanmohan, the god of erotic love.

The prince who was now gifted with newfound strong physicality was name Bhagiratha as he was born of two vulvas (bhagas).

\section{6 of 20}

BANKIM CHANDRA CHATTERJEE-INDIRA (1873)

One of the earliest novels in Renaissance Bengal dealing with

homosexuality finds its expression in Bankim Chandra Chatterjee's Indira. Hailed as one the greatest novels of the $19^{\text {th }} \mathrm{C}$., Indira tells the story of its titular character's intense and passionate friendship and affair with her friend, Subhashini. 
In spite of being married, Indira finds herself drawn towards Subhashini.

" I can hear that the men have finished having their meal. Romen Babu will soon return to the room-and I will have to leave. Of all the things

that you taught me; I loved the kiss the most. Come, let us learn it again together."

\section{SUNIL GANGOPADHYA - THOSE DAYS}

Those Days by Sunil Gangopadhya was first published serially as a novel in a magazine. Set in the backdrop of Renaissance Bengal the novel's protagonist, Kaliprassana Singha finds himself amidst the company of Bengal's greatest men, from Debendranath Tagore to Ishwar Chandra Vidyasagar. Gangopadhya's uninviting portrayal suggesting Michael Madhusudan Dutt of indulging in homosexual acts and the dynamic he shared with women, made public and critics alike question the need to portray a public figure as such. It was labelled blasphemous and perturbed the readers greatly.

\section{PRAVARTAK}

Pravartak, also known as Naya Pravartak since 1995, was one of the earliest LGBTQ magazines published in Kolkata from 1991 to 2000.The magazine was published in both English and Bengali.

It was brought into circulation again in 1993 by Counsel Club, a newly-formed support group for gender and sexual minorities. In the course of its private circulation, the magazine was distributed by word of mouth among LGBTQ people, community, institutions and events as well as the Counsel club meetings.

\section{MUGHAL EMPIRE}

During the Mughal Empire, Urdu poetry of the late medieval era used the term "chapti" to address sex between people of same genders. "Amarad Parast" referred to those with preference for young males. In the courts of the

\section{7 of 20}

Emperors and even in his 'harems' special administrative posts were reserved for trans men and women who were in favour of the King and loyal to Him.

Various historical facts have suggested that Alauddin Khilji had a fascination for young boys. Fascinated by effeminate beauty, he bought a slave during his Gujarat conquest named Malik Kafur. This is documented in many books including the 'Tarikh-e-Firozshahi'.

According some historians, the Mughal Emperor Babur was also attracted towards young boys. As per the Journal of Pakistan Medical Association, Babur developed homosexual tendency and started to love a 17-year-old boy in Urdu bazar. Some sources claim, the historical Babri masjid was named after Babri who was Babur paramour.

\section{Babur says in Baburnama :}

"Up until then I had no inclination for any-one, indeed of love and desire, either by hear-say or experience, I had not heard, I had not talked."

In Journal of Pakistan Medical Association Babur's homosexuality is indicated-

"Throughout his autobiography, he never mentions even a remote form of infatuation, leave alone love for any woman.... But a boy he first met at a

marketplace in Kabul has his heart longing for him. In his own words, he was 'maddened and afflicted' for this boy by the name of Baburi."

|www.worldwidejournals.com
Sarmad, a Jewish companion of Dara Shukoh, was put to death because of the multiple allegations that were raised against him. Before his execution when the Mughal court was looking for reasons to charge him for treason, they did not consider homosexuality to be a reason enough to punish him.

\section{EFFECT OF BRITISH IMPERIALISM ON THE LGBTQ} COMIMUNITY The homosexual and transgender people in India suffered a setback

when the British rule was established. Being under British hegemony meant that the Monarch of England was the head of the colonies and the Church of England as well. Back in the late 1700s the Church of England condemned homosexuality to be a crime and thus the sexual attitudes had to change and tone down.

Section 377 under the Indian Penal Code was introduced by the British Imperial government in 1861. Formulated on the basis of the Buggery Act of 1533, it made sexual activities "against the order of nature" illegal.

When we talk about queer characters and stories in Imperial India, we hardly find any substantial representation of them. However, England and America that once had laws that made gay sex illegal and did not recognise people with queer sexuality, still had an exclusive representation of the

\section{8 of 20}

community in their culture and literature. Oscar Wilde, famously, was openly gay and insinuated his sexuality in his works and celebrated for it. Then how is it that even more 60 years after the British have left, India still fails to embrace its LGBTQ community in its literature?

\section{- DECRIMINALIZING OF 377}

The LGBTQ community in India triumphed in 2018 when the Supreme Court unanimously stated that the section was unconstitutional and scraped.

Navtej Singh Johar \& Ors. Vs Union of India thr. Secretary Ministry of Law and Justice was the case fought by Menaka Guruswamy, a Senior Advocate at the Supreme Court of India and Arundhati Katju, an Advocate at the Supreme Court. The landmark case ruled in favour of adults engaging in consensual sex and ruled that the section was unconstitutional in view of 'the rights to dignity and privacy which falls under the right to life and liberty guaranteed by Article 21.'

Though the section stands decriminalised presently, when asked to sample group of 50 people, if transphobia and homophobia still exists in our society, a staggering $94 \%$ of the responses agreed to it.

\section{IS LGBTQ LITERATURE A TABOO IN INDIA?}

" इस पुस्तिकाकेसमपपणकेयोग्कोई व्यस्ति ह ििंदी-साह त्य मेंनीििहमला यद्वहप कु ल्लीकेगुणबो ोतो में क, परगुणकेप्रकाशमेंसबघबराय।"

\section{कु ल्लीभाट' \\ -सूयपकािितहिपाठीहनराला}

translation.

(No person worthy of the dedication of this booklet was found in Hindi literature, although Kulli's qualities are in abundance, but the expression of such virtues terrifies everyone.)

'Kulli Bhat'

Suryakant Tripathi Nirala

Nirala addresses the readers from the very start that homosexuality was not accepted by the society and tabooed which made it difficult for such people to come out and express themselves for who they were as they feared being 
outcasted. In the survey when asked if there is enough representation of LGBTQ stories in modern Indian literature, $78.7 \%$ of the responses stated that they do not find enough representation.

Do you think the representation of LGBTQIA+ characters in modern Indian literature is sufficient and justified as opposed to Foreign literature?

47 responses

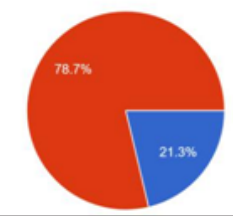

\section{Y No}

As stated by Nirala ;

" रूहिवाहदयोिि केहलए येदोष ै, पर साह त्यकार केहलए, हवशेषताहमलनेपर , गुणोगा।"

'कुल्लीभाट'

-सूयपकािितहिपाठीहनराला

translation.

"This maybe a fault for the conservatives, but for the author, if a good trait is found, it will be a virtue." “"

'Kulli Bhat'

-Suryakant Tripathi Nirala

As observed in the survey the conservative thought associated with homosexuality hinders people to approach LGBTQ literature or even just the idea of it with an open mind.

Lihaaf (1942) by Ismat Chughtai, for instance, had to undergo a trial as the short story features explicit lesbianism. Rabbu and Begum Jaan are the two women who play the main role to challenge the skepticism associated with same sex relationships. A quote from the short story states-

'"The quilt looked perfectly innocent in the morning."

One may ask that why should one have to prove their innocence to justify their love or their sexual orientation?

'Chocolate' (May 31, 1934) by Pandey Bechan Sharma 'Ugra' presents a love affair of Dinkar Prasad with a young boy named Ramesh. The writer calls Ramesh as Dinkar's 'chocolate'. When asked by a character Mohan what 'chocolate' means, Dinkar's friend Gopal replies,

" Chocolate is the name of those innocent, tender and beautiful boys of the country whom society's demons push into the mouth of ruin to quench their lusts." (trans. Ruth Vanita, Same Sex Love in India).

According to Gopal, homosexuality was a sin and Dinkar was that 'demon' who committed sin and tricked innocent Ramesh to become a part in his wicked ploy. Dinkar's justifications for his actions and his sexual orientation is baseless in the eyes of society.

An irked Manohan dissatisfied with Dinkar's explanations says, "You will then see what he has to say. He will scan history, shave the

head of the puranas, and prove that boy-love is also natural not unnatural. The day I talked to him he told me, on the basis of an English book, that even Socrates was guilty of this offence. He said that Shakespeare too was the slave of a beautiful friend of his. He talked of Mr. OscarWilde too."

(trans.)

'Same Sex Love'

-Ruth Vanita
Manohan claims homosexuality to be an epidemic. To him it is one of the reasons why boys are being distracted from education as they spend time becoming more effeminate.

Banarasidass Chaturvedi, one of Ugra's critics expressed his dissatisfaction with the theme in chocolate. He calls Ugra a 'ghaslet litterateur'(kerosene literature). Chaturvedi found homosexuality to be against the norms and is irked and disturbed by Ugra's story as he accuses him of promoting the 'ills' in the society vis-à-vis homosexuality.

In 1978, Shakuntala Devi published the first Indian study about homosexuality. It opened the doors and gave opportunities on research of queer anthropologies.

In the ' 90 s, the rebirth of LGBT narrative was seen in the work of Braham Singh in his book 'Bombay Swastika'. He states in an interview,

'Mine is not a book on homosexuality but a book in which a homosexual character intervenes in the most absolute normality as part of history, as part of the world. I grew up with a gay brother and for me, relating to a different sexuality is like dealing with a gearing and always existent part of society."

The difference of the treatment meted out to homosexuals in India and abroad is starkly contrasted in the novel A Life Apart or Past Continuous (2008) by Neel Mukherjee.The protagonist, Ritwick finds himself closeted and unable to express fully in India and lives a dual life. He finds freedom in England where homophobia is in the past. Ritwick in his own words claims,

"..... I can be free here.... the opportunity to be myself here is something I value immensely."

Raj Rao's 'Hostel Room 131' sees its two protagonist Siddarth and Sudhir pursue an affair while studying at the same college. Rao's narrative is a reflective of the homophobia prevalent in India. The novel starts with Siddarth lodging a complaint against Sudhir's homophobic family. They have locked up Sudhir and not allowed him to contact anyone and launched a police complaint against Siddarth who is arrested and jailed. Siddarth says,

"What's my crime? For me, love is a full-time job. One is a lover exactly the way one is a scientist or a doctor or a lawyer... Besides, who on earth will love Su like that? No mother or father or sisters or brothers or uncles. No wives...."

Siddarth's comment that no one will accept Sudhir the way he does highlights the fact that even family members find it incomprehensible to love their child who might come out as gay.

"If anyone interpreted their actions as proof of their gayness, they would accuse him of possessing a sinful mind."

The young couple however are scared to be seen in public and later on in the novel, faces threats and blackmail from a fellow student, Ravi Humbe who catches them in a compromising situation. Later Sudhir's family members threaten Siddarth, " 'Get out of our house, you chhakka, you homosexual, and never come anywhere near the place again if your life is dear to you,' he screamed at the top of his voice, as he held Siddarth by the shoulder and pushed him out of the house." The homophobia in the family is due to societal norms and it is so deeply embedded that they perceive it to be a sin and hence takes their son to a remote ashram to 'cleanse' him of his homosexuality by electroshock therapy.

For Siddarth and Sudhir, as a gay couple, it will never be 
possible to stay together socially or be united in the bonds of matrimony in 1980s India. India was homophobic then and still is and hence it will not be easy for them to live together, at least legally. So, the couple with help of a gay support group incurs the medical expenses for Sudhir's sex change operation to enable the two to get married.

Mahesh Dattani's famous play, Bravely Fought the Queen first staged in Mumbai in 1991, is essentially a story about the oppression of one's true sexual identity. In the play, Praful and Nitin are in, what society would view as, unnatural relationship. So, to hide their homosexuality from the world, Praful gives away Alka, his sister in marriage to Nitin.

The play portrays homosexuality in a light that is quite realistic. In a deeply homophobic society, in order to survive one needs to reshape their identities, sacrificing their desires, even if that means entering a 'social' marriage to keep up appearances, so that behind closed doors they can carry on with the "illicit affairs".

In another play, On a Muggy Night in Mumbai, a group of friends, whose orientations ranges from lesbian to gay to straight come together in an apartment room. One of the gay characters, Ranjit says, "I can't seem to be both Indian and gay." On a Muggy Night in Mumbai is one of the first Indian plays to showcase same sex couples. It deals with the pertinent issue of self-acceptance of an individual with regards to their sexuality. Prakash's identity crisis to come to terms with his sexuality eventually leads him to take the extreme step of attempting suicide. He says,

"Where do I begin? How do I begin to live?.......Will You help me?What

makes a man a man?"

He is afraid to open up his true self to the society in fear of lack of acceptance and homophobia and internal conflict.

Manvendra Singh Gohil, the crown Prince of Rajpipla, Gujarat is one of the openly gay royalty in India and in the world as well. He came out in an

\section{3 of 20}

open letter in the Vadodara edition of the newspaper of 'Divya Bhaskar'. On his coming out he stated in the segment 'Gay Around the World' on The Oprah Winfrey Show,

"I knew they would never accept me for who I truly am, but I also knew that I could no longer live a lie....... I came out...because I wanted people to

openly discuss homosexuality since it's a hidden affair with a lot of stigma attached."

Since July 2010, Gohil has served as the editor of a gay magazine for men called "Fun" published exclusively in Rajpipla. Gohil also runs a charity called The Lakshya Trust which works with the LGBT community in India to raise awareness on HIV/AIDS. In 2018 Manvendra opened up his palace grounds as a sanctuary to house vulnerable individuals who have been outcasted and rejected by their families for coming out.

\section{TRANS LITERATURE in INDIA}

Trans Literature is a term used to address the literary works produced and written by and portrays not only transgender people but also others of various gender identities.

The collective term used to refer to transgender/s in India is hijra/s.

|www.worldwidejournals.com
Annamarie Jagose in Queer Theory: An Introduction (1996) says:

'Hijras are culturally institutionalized as an alternative to mixed gender role, neither man nor woman, neither male nor female. Mostly the Indian female is rather too emphatically writ over their costumes, gestures, manners and even facial expressions. However, two symbolic acts distinguish them from the feminine figure: the distinctive handclap with which they announce their public presence and the other is the actual or threatened lifting of the sarees to expose their genitalia to protest against a hostile audience.'

Laxmi Narayan Tripathi, a human rights activist, details personal approach to her life as a hijra and the challenges she has to face on a daily basis; 'Hijras are sexual minority that is visible, and yet are treated as the invisibles."

Manobi Bandyopadhyay, the first transgender principal in India, was born as Somnath Bandyopadhyay. She became the principal at Krishnanagar Women's College with a Ph.D. in Bengali Literature. Selected for this post purely on merit, Manobi still has to endure the blunt transphobia prevalent in Indian society.

In 1995, she started the first Bengali magazine for transgenders, Abomanob meaning subhuman. She is also the author of two books - Ontohin Ontorin Prositovortika (Endless Bondage) which went on to become a best seller. Another book by her other is Third Gender in Bengali Literature.

A Gift of Goddess Lakshmi is a biography of Manobi Bandyopadhyay written by journalist, Jhimli Mukherjee Pandey. It traces Manobi's story of transformation from a man into a woman. It showcases the birth and life of Somanath and his journey to become Manobi and the challenges she faced throughout the journey and how she continued to pursue academics despite the adversities. Her example has set new standards of achievement. The book mirrors our society's treatment and reaction to the transgenders in our society that it is still underlined with transphobia and othering.

A.Revathi in her landmark book, 'The Truth About Me: A Hijra Life Story' explains the discrimination the hijras suffer just to be accepted by the masses.

'In our society we speak the language of rights loud and often but do the marginalized really have access to these rights in the name of sex, sexuality, caste and religion..."

Transgender individuals from a young age encounter gender dysphoria that eventually leads them to identify themselves as a gender different than the one assigned to them at their birth. Due to lack of awareness, they rarely know how to navigate such diametrically opposite experiences. Hence many children might get bullied and are not able to express themselves articulately.

The novel The Ministry of Utmost Happiness by Arundhati Roy presents a boy Aftab who in the course of the novel comes to identify himself as a girl. In his childhood when he had started taking classes under Ustad Hameed Khan he was bullied by fellow classmates:

'He's a she. He's not a he or a she. He's a he and a she. She-He, He-She, Hee! Hee! Hee!"

This made Aftab quit his classes at Khan's. This is an example of how social transphobia that often leads to bullying takes its toll on a child and his future.

The only place he thought his dream would turn into reality was 'Khwabgah'- the house of dreams, where people like him went and has fulfilled 
their dreams by transforming themselves into a woman. Aftab's transformation to Anjum was complete the moment she stepped into Khawbgah. Khawbgah was called so because it was the place where these 'holy souls trapped in the wrong bodies were liberated.'

Their internal turmoil was much more dangerous and chaotic than the chaos in the outside world;

'But for us the price-rice and school-admissions and beatinghusbands and cheating-wives are all inside us. The riot is inside us. The war is inside us. Indo-Pak is inside us. It will never settle down. It can't."

Quite a similar situation is seen in Revati's book as well where she is bullied by her classmates:

"My classmates.... they would chant 'girl-boy!' 'Ali' 'Number 9'. My heart

would sink at those words, but I also felt faintly gratified and even happy that these boys actually conceded that I was somehow a woman."

Revati also mentions that she was often caned for 'not being brave like a boy'. Not only did the outside world but Revathi's family environment also proved to be a toxic place for her to accept her identity. Her siblings would call her 'motherfucking sissy'. There was a lack of family support and her brothers were dismissive of her achievements. They'd taunt, "We knew this girl-boy would fail. We knew it even then, when he started to dress up as a girl, that he was up to no good."

Due to societal and familial pressure Revathi tried to force 'masculinity' on herself but would feel troubled and uncomfortable when she found herself drawn towards men and not women.

"A woman trapped in man's body was how I thought of myself."

She felt more comfortable in women's clothing and men's clothing felt to her as if she was wearing a disguise.

"God has made us this way, I thought, and we have no work of our own, our parents don't understand us and this world looks upon us with distaste.... Above all, we wanted to live as human beings do, with dignity."

Trans people seek independence and wish to live without guilt or shame for being who they are, the way they are. They are often denied opportunities and employment simply based on the fact of their identity. Revathi mentions in her book 'The Truth About Me:A Hijra Life Story':

"If we're to employ you, you'd be the ruin of all the boys here."

She goes on to say with remorse, "...none of it was my fault- the way the world perceived me and refused to accept me, the manner in which it snatched away my rights and made it difficult for me to earn a living except through begging and sex work, the violence it contemptuously inflicted on me."

The discrimination and stigma around employing trans people deprive them of a respectful living and force them into begging and sex work. Even in trying to earn a living whether that be sex work, they are ostracised for it by the law as well. In many instances, several trans women and men have been arrested for being in this profession or even just being suspected to be a sex worker, just like in the case of Revati. Trans people have to bear the blunt of discrimination and torture in jails as well where they are brutalised, stripped naked and subjected to assault, both physical and sexual.

\section{ABSENCE OF INDIAN LGBT NARRATIVES IN SCHOOL CURRICULUIM}

The question asked in the survey conducted was,

"Studies have shown the schools and college libraries do not have sufficient LGBTQIA + YA (Young Adult) books and nonfiction novels. If such books were to be introduced do you think it will help tackle homophobia and transphobia?"

$87.8 \%$ of the responses agreed to the idea of introducing gay literature for young adults in school.

Studies have shown the schools and college libraries do not have sufficient LGBTQIA+ YA(Young Adult) books and non- fiction novels. If such book...nk it will help tackle homophobia and transphobia? 49 responses
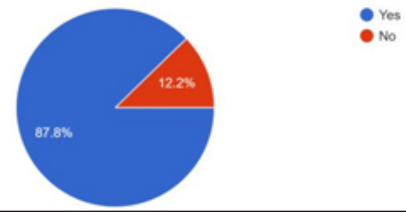

But why is it that we see that there aren't sufficient books prescribed in the curriculum of schools and universities?

First and foremost, LGBTQ narratives in Indian novels are a rarity. Furthermore, the well-known ones which are even critically acclaimed is of salacious nature.

Many instances of expressing one's homosexuality or coming out is shown through explicit scenes that borders on fetishization and titillating.

One such instance can be found in R. Raj Rao's The Boyfriend;

'He had all the characteristics that definedYudi's type. He was on the thinner rather than the fatter side; his skin was the colour of Cadbury's chocolate (and as smooth too); he had straight (as opposed to curly) hair."

Quite an unusual and perhaps disturbing explicit observation is made of the male genitalia by theYudi, the protagonist when he says,

" Where he wanted to bite into a cucumber, what was on display was a mere chilli."

In Hostel Room 131, R. Raj Rao does not mince his words while describing explicit sex scenes between Siddarth and Sudhir multiple times during the course of the novel.

'Siddarth did not hold his horses. Even as he initiated a conversation with the chap, he initiated sex...All along, as he spoke, Siddarth let his hand sit in Sudhir's. His heart palpitated. Sudhir didn't dis-engage himself from Siddarth's grip, making the latter confident...Occasionally he rubbed his finger against Sudhir's palm. This was an obscene gesture that meant, 'I want to screw you'."

A stark contrast is noticed in the manner young homosexual couples and their journey with discovering and showcasing their sexuality are portrayed in foreign YA literature. Becky Albertalli's Simon vs. the Homo Sapiens Agenda (2015) tells the story of teenager, Simon Spier, a closeted high school student who is forced to come out after a blackmailer leaks his personal emails written to another closeted classmate codenamed, 'Blue' he has fallen in love with. The novel beautifully showcases the journey one goes through while coming to terms with their sexuality that is challenging albeit fruitful and the love affair between Simon and Blue with sublimity and innocence without the need to forcefully inculcate random, explicit and uncomfortable sex scenes.

\section{CONCLUSION}

The LGBTQ narratives in the Indian society is still growing and evolving at par with the changing times. Significant progress 
on social and legal fields have been made to protect people from this community but there are unfortunately many whose mentality and perception of this community is still dated.

The media representation being a vehicle of influence has not done adequate justice to the cause of eradicating homophobia and transphobia. A few instances of such misrepresentation in the popular culture includes an Over the Top (OTT) series called 'Man to Man' featuring Adah Sharma, a straight, cisgender woman playing a trans woman. Akshay Kumar's recent film, 'Laxmii'(2020) has been accused by LGBTQ netizens of vilifying and caricaturizing trans people. Such a gimmick and transphobic portrayal could have impactful impression on people regarding a community they don't understand.

The trans community have historically being used as a crass comic relief and sub-humanly portrayed in the Indian film narratives. The various stereotypical narratives see homosexual and transgender characters in films being often played by cis and heterosexual artists whose interpretation of the role is to make a gay man effeminate and a lesbian, a tomboy and a trans person as obscene thus harbouring and propagating dated, biased misconceptions.

Young and novice writers from the gay and trans community are better representatives to bring forth such stories that seem authentic and feel humane. Throughout India, organizations and platforms such as Sangama who work with LGBTQ community and its members who feel oppressed because of their sexuality and live with HIV. Varta Trust, a non-profit organisation which creates dialogue on gender and sexuality in India through publications, public events and research and advocacy. Sappho Equality is an activist forum for lesbians and trans individuals which is taking active steps to combat homophobia and transphobia and demand for legal recognition of the rights of people from the LGBTQ community at large.

QCC (Queer Chennai Chronicles), an Indian LGBT literary organization aims to promote lesbian, gay, bisexual, transgender and queer literature through programs that encourages and brings to the spotlight the development of aspiring writers and through annual Queer Lit Fest in Chennai, India.

\section{REFERENCES}

[1] Dececco, P. and Pattanaik, D., 2014. The Man Who Was A Woman And Other [2] Queer Tales From Hindu Lore. Hoboken:Taylor and Francis.

[4] Raj Rao, R., 2012. Hostel Room 131. Camberwell,Vic.: Penguin. Mukherjee, N., n.d. A Life Apart. New York: W.W. Norton \& Company, @2008. Revathi, A. and Geeta,V.,n.d.The Truth About Me.London (Penguin Books)

[5] JPMA - Journal Of Pakistan Medical Association

[6] Macmillan,P., Vanita, R. and Kidwai, S., 2016 . Same-Sex Love In India. New York: Palgrave Macmillan

[7] Dattani, M., 2004. On A Muggy Night In Mumbai. Cambridge [England]: Proquest LLC.

[8] Chughtai,I., 1992.Lihaaf.

[9] Tripa thi ,S.,2004.Kulli Bha tạ.Nayi Dilli :R jakamalaPrak sána.

[10] Dattani, M.,n.d. Bravely Fought The Queen.

[11] Pattanaik,D.,n.d. Shikhandi and OtherTales They Don't TellYou 